\title{
Avidity of IgG for Rubella: An Evaluation of the Need for Implementation at the Materno-Infantil Presidente Vargas Hospital in Porto Alegre, Rio Grande do Sul, Brazil
}

Reis, M.M. ${ }^{1,2}$, Tessaro, M.M. ${ }^{1}$, Cruz e Silva, J. ${ }^{3}$, Giordano, S.A. ${ }^{1}$ and d'Azevedo, P.A. ${ }^{2}$

\author{
${ }^{1}$ Pathology Service of the Hospital Materno Infantil Presidente \\ Vargas (HMIPV), ${ }^{2}$ Department of Microbiology and Parasitology \\ of the Fundação Faculdade Federal de Ciências Médicas de \\ Porto Alegre (FFFCMPA), ${ }^{3}$ Faculty of Pharmacy of the Universidade \\ Luterana do Brasil (ULBRA), Porto Alegre, RS, Brazil
}

\begin{abstract}
Rubella serum assays performed in the laboratory of the Materno-Infantil Presidente Vargas Hospital (HMIPV) from 1998 to 2002 were reviewed to determine if IgG avidity assays should be implemented. IgG was determined using the Enzyme Linked Fluorescent Assay, ELFA, VIDAS® system, bioMérieux or the Microparticle Enzyme Immunoassay, MEIA, Axsym ${ }^{\circledR}$ system, Abbott, and IgM was determined using the ELFA, VIDAS ${ }^{\circledR}$ system, bioMérieux, a capture format assay. Specific IgG was assayed in 2,863 samples, with positive results for $84 \%$ of the patients, for the most part with high levels of antibodies. IgM was assayed in 2,851 samples, being positive in 14 $(0.49 \%)$ and inconclusive in $25(\mathbf{0 . 8 8} \%)$. Serology for toxoplasmosis was also positive or inconclusive in 5 patients. After a cost-effectiveness analysis, it was decided not to implement avidity assays, considering that the HMIPV is a public institution, with limited funding. Difficulties concerning the integration of the Clinical Pathology Service with the Clinical Staff of the institution were also considered.
\end{abstract}

Key Words: Rubella virus infection, congenital infection, avidity of IgG for rubella, serology for rubella virus.

Primary infection by the rubella virus is benign and is usually subclinical, but even if the mother has no symptoms the fetus may be severely affected, especially if infection occurs during the first 12 weeks of pregnancy [1-5]. The risk of teratogenicity if the mother is infected during the first eight weeks of gestation is nearly $100 \%$ [6]. The dissemination of the virus to the fetus probably begins with placental infection during maternal viremia. Possible mechanisms of cytopathogenicity include induction of apoptosis by the virus and inhibition of cell

Received on 17 January 2004; revised 11 June 2004.

Address for correspondence: Dr.Pedro Alves d'Azevedo, Fundação Faculdade Federal de Ciências Médicas de Porto Alegre, Sarmento Leite street 245/211 - Porto Alegre, RS, Zip code: 90050-170, Brazil. Phone: 5551 32248822. Fax: 5551 32269756. E-mail:pedroaze@fffcmpa.tche.br

The Brazilian Journal of Infectious Diseases 2004;8(3):249-254 (C) 2004 by The Brazilian Journal of Infectious Diseases and Contexto Publishing. All rights reserved. division [7-11]. When the fetus is infected after the $18^{\text {th }}$ week of gestation, organogenesis is already complete, making the presence of anomalies much less probable [6].

The rubella virus establishes a chronic infection in the fetus, and its elimination may take years [12]. Manifestations of congenital infection by the rubella virus may be transient with spontaneous regression, including neonatal thrombocytopenic purpura, hemolytic anemia, and hepatitis; permanent: deafness, congenital heart disease, cataract, glaucoma, pigmentary retinopathy, and mental retardation; and tardive: diabetes mellitus, hypo- and hyperthyroidism, and panencephalitis [13-16].

Serum assays have been used to evaluate immunity to the virus, determining the need to vaccinate women at reproductive age or to diagnose infection. The diagnosis of infection is serologic and is based on the presence of specific IgG and IgM antibodies [12,17]. 
More recently, assays of the avidity of $\mathrm{IgG}$, i.e. the strength of IgG binding to a multivalent antigen of the virus, have been used to distinguish recent from old infections in individuals with high IgG levels $[18,19]$. At the onset of the immune response (acute phase), the IgG generated by the antigenic stimulus has low avidity, i.e. binds with less avidity to the antigen, but as time goes by in the convalescence, after the first 2-4 months of infection, avidity increases.

Symptomatic postnatal primary infection is serologically diagnosed through seroconversion, negative $\mathrm{IgG}$ reaction during the exanthem but positive reaction after two weeks, presence of IgM, and low avidity of IgG. An isolated sample with positive specific IgG and IgM levels and low avidity of IgG in the mother must raise a suspicion of asymptomatic primary infection [12].

In immune, as well as in vaccinated females, $\operatorname{IgG}$ is present, avidity is high, and IgM is absent. The IgG level is important to indicate susceptibility to reinfection, common in females with levels below $10 \mathrm{IIU} / \mathrm{mL}$ [12]. Reinfections, for the most part asymptomatic, pose a low risk to the fetus, but they may develop with the presence of IgM, particularly in the reinfection of vaccinated females [20-22]. Reinfection is suspected in a specific sample when the specific IgG is positive and the avidity of $\mathrm{IgG}$ is high, accompanied or not by IgM [12]. The differential diagnosis between asymptomatic primary infection and reinfection is extremely important, yet difficult, because under both conditions antibody titers are increased and IgM may be present. Avidity of IgG may be useful to distinguish between the two conditions, being low in primary infection and high in reinfection [23,24].

Specific IgG determination is performed through enzymatic techniques with chromogenic (such as the Enzyme-Linked Immunosorbent Assay; ELISA), fluorescent (MEIA, ELFA), or chemiluminescent substrates $[12,17]$. The results, expressed in IU/mL, are compared to standards provided by the World Health Organization - International Laboratory for Standardization in Biology (Copenhagen, Denmark). Specific $\operatorname{IgM}$ is determined preferentially using a capture assay format, which dispenses with the serum treatment stage to eliminate the rheumatoid factor and maternal IgG, and through anti-VR conjugates, $\mathrm{F}\left(\mathrm{ab}{ }^{\prime}\right) 2$ fraction $[25,26]$. The determination of avidity of $\operatorname{IgG}$ complements the serologic diagnosis in the IgG and IgM-positive mother.

In order to determine the need for implementing avidity of IgG in the Hospital Materno-Infantil Presidente Vargas, we reviewed the results of rubella serum assays for specific IgG and IgM determination performed in the laboratory from 1998 to 2002.

\section{Material and Methods}

Samples from the Prenatal, Pediatric or Pregnant/ Parturient and hospitalized children wards were referred to the laboratory to be serologically tested for rubella. The blood samples were obtained through venous puncture using the Vacutainer System in a tube with separating gel. In the Immunology Section, each sample was centrifuged and the serum processed by the ELFA method, VIDAS® system, bioMérieux or MEIA, Axsym ${ }^{\circledR}$ system, Abbott for IgG, and ELFA, VIDAS $®$ system, and bioMérieux for IgM, following the recommendations of the respective manufacturers. We suggested repeating the test two weeks later in all cases of indeterminate results, both for IgG and IgM.

Reference ranges for IgG in the ELFA were as follows: negative: below $10 \mathrm{IU} / \mathrm{mL}$, inconclusive: between 10 and $15 \mathrm{IU} / \mathrm{mL}$, and positive: equal to or above $15 \mathrm{IU} / \mathrm{mL}$. For the MEIA they were: negative: below $5 \mathrm{IU} / \mathrm{mL}$, inconclusive: between 5 and $10 \mathrm{IU} /$ $\mathrm{mL}$, and positive: equal to or above $10 \mathrm{IU} / \mathrm{mL}$. For $\mathrm{IgM}$, reference ranges for ELFA were: negative: below 0.80 , inconclusive: between 0.8 and 1.2 , and positive: equal to or above 1.2.

\section{Results}

Of the 2,863 patients tested for specific IgG, 2,406 $(84 \%)$ were positive, with levels ranging between 15 and $50 \mathrm{IU} / \mathrm{mL}$ in $18.4 \%$, between 50 and $300 \mathrm{IU} / \mathrm{mL}$ in $63 \%$, and $>300 \mathrm{IU} / \mathrm{mL}$ in $18.2 \%$ of patients. 
Table 1. Data on patients with positive IgM for rubella

\begin{tabular}{lcccc}
\hline Patients & Age & IgG & IgM & Date \\
\hline P1 & 14 months & 119 & 14.62 & 02.26 .99 \\
P2 & 1 year & 154.3 & 4.99 & 06.19 .02 \\
P3 & 16 months & $>400$ & 1.24 & 12.03 .98 \\
P4 & 9 years & 89.5 & 1.81 & 10.31 .01 \\
P5 & 19 years & 67.5 & 2.25 & 02.27 .02 \\
& & 65.3 & 0.84 & 05.22 .02 \\
P6 & 19 years & 146.0 & 2.0 & 11.17 .99 \\
P7 & 21 years & $>400$ & 1.64 & 09.19 .00 \\
P8* & 17 years & 32.3 & 1.23 & 03.06 .01 \\
P9 & 25 years & $>400$ & 1.43 & 05.03 .00 \\
P10 & 31 years & 138.0 & 1.27 & 04.29 .99 \\
P11 & 26 years & $>400$ & 1.27 & 04.03 .00 \\
& & $>400$ & 0.91 & 06.19 .00 \\
P12 & U & 128.2 & 6.94 & 05.16 .02 \\
P13** & 4 months & $\mathrm{N}$ & 2.20 & 09.10 .00 \\
P14 & 4 months & $\mathrm{N}$ & 1.94 & 02.23 .99 \\
\hline
\end{tabular}

$\mathrm{P}=$ positive, $\mathrm{N}=$ negative, $\mathrm{I}=$ inconclusive, $\mathrm{U}=$ unknown. *Toxo $\mathrm{IgG}=31.7(\mathrm{P})$, $\operatorname{IgM}=1.1(\mathrm{P})$. **Toxo $\operatorname{IgG}=\mathrm{N}, \operatorname{IgM}=0.63$ (I).

Inconclusive results were obtained in 37 patients (1.3\%), but none of these returned to be tested again. In 420 patients $(14.7 \%)$, the results were negative.

Of the 2,851 patients tested for specific IgM, 2,812 (98.6\%) were negative, $25(0.88 \%)$ were inconclusive, and $14(0.49 \%)$ were positive. The results of patients with positive and inconclusive IgM are shown in Tables 1 and 2, respectively.

In two samples (P13 e P14), from two 4-monthold females, IgM was positive and $\mathrm{IgG}$ was negative. We did not have obstetric (mother's serum) or clinical data regarding these patients, who also did not return to be tested again. Patient 13 had an inconclusive IgM for toxoplasma.

Among the results of inconclusive IgM (Table 2), two samples were from children. Patient 2 had positive results for toxoplasmosis, with extremely high levels of IgM, observed in acute infection with T. gondii. Patient 6 also presented results indicative of recent toxoplasmosis, probably acquired within the last two years, with high levels of $\mathrm{IgG}$ and low levels of $\operatorname{IgM}$. Patient 8 presented inconclusive levels of $\operatorname{IgM}$ for toxoplasmosis.

\section{Discussion}

Vaccination campaigns have considerably reduced the incidence of congenital infection with the rubella virus [27]. In our sample $81.2 \%$ of the patients, mostly adult females at reproductive age, were found to have high levels of specific IgG. The 37 patients with inconclusive $\mathrm{IgG}$ did not return to be tested again as recommended, possibly because they were $\operatorname{IgM}$ negative.

The IgG avidity test is indicated as an aid in the diagnosis of symptomatic primary infection and to make the differential serological diagnosis between asymptomatic primary infection and reinfection with the rubella virus, especially in pregnant women. 
Table 2. Data on patients with inconclusive IgM for rubella

\begin{tabular}{|c|c|c|c|c|}
\hline Patients & Age & IgG & IgM & Date \\
\hline P1 & 2 years & $>400$ & 1.10 & 01.13 .00 \\
\hline $\mathrm{P} 2 *$ & 2 years & 203.4 & 0.89 & 03.19 .01 \\
\hline P3 & 17 years & 133.0 & 1.12 & 10.23 .00 \\
\hline P4 & 36 years & 317.0 & 1.12 & 04.10 .00 \\
\hline P5 & 16 years & 107.8 & 1.04 & 05.06 .02 \\
\hline P6** & 24 years & 375.0 & 1.01 & 09.05 .00 \\
\hline P7 & 15 years & 31.1 & 1.0 & 11.22 .00 \\
\hline $\mathrm{P} 8 * * *$ & 27 years & 16.9 & 0.98 & 12.04 .00 \\
\hline P9 & 30 years & 149.0 & 0.94 & 04.29 .99 \\
\hline P10 & 24 years & 347.0 & 0.93 & 02.08 .00 \\
\hline P11 & 21 years & 46.0 & 0.90 & 01.21 .00 \\
\hline P12 & 20 years & 173.0 & 0.89 & 09.28 .00 \\
\hline P13 & 26 years & 165.0 & 0.86 & 09.01 .00 \\
\hline P14 & 16 years & 110.0 & 0.84 & 06.07 .99 \\
\hline P15 & 42 years & $>400$ & 0.82 & 03.29 .01 \\
\hline P16 & 23 years & 237.0 & 0.81 & 04.08 .99 \\
\hline P17 & $\mathrm{U}$ & 32.0 & 0.86 & 11.11.98 \\
\hline P18 & $\mathrm{U}$ & 257.0 & 1.17 & 02.09 .99 \\
\hline 19 & $\mathrm{U}$ & 451.0 & 1.01 & 11.27 .02 \\
\hline P20 & $\mathrm{U}$ & 85.1 & 0.84 & 03.05 .02 \\
\hline P21 & $\mathrm{U}$ & $>400$ & 0.83 & 01.17 .02 \\
\hline P22 & $\mathrm{U}$ & 52.4 & 1.17 & 03.23 .01 \\
\hline $\mathrm{P} 23$ & $\mathrm{U}$ & 283.2 & 0.82 & 11.23 .00 \\
\hline P24 & $\mathrm{U}$ & 92.0 & 0.87 & 06.13 .00 \\
\hline $\mathrm{P} 25$ & 17 years & $\mathrm{N}$ & 0.81 & 12.22 .00 \\
\hline
\end{tabular}

$\mathrm{P}=$ positive, $\mathrm{N}=$ negative, $\mathrm{I}=$ inconclusive, $\mathrm{U}=$ unknown.* Toxo $\mathrm{IgG}=>300(\mathrm{R})$, $\operatorname{IgM}=15.89(\mathrm{P})$. ** Toxo $\operatorname{IgG}=>300(\mathrm{R}), \operatorname{IgM}=0.97(\mathrm{P}) . * * *$ Toxo $\operatorname{IgG}=22.7$ (R), $\operatorname{IgM}=0.56$ (I.)

In the original group, we found 7 patients who could have benefited from an $\operatorname{IgG}$ avidity test. In 2 patients, the second sample (P5 at 2 months and 25 days, and P11 at 2 months and 13 days) showed a slight reduction of specific IgM levels. In the group of patients with inconclusive $\mathrm{IgM}$, none returned to be tested again.

The highest IgM levels occur between 4 and 35 days in the ELISA, becoming negative within 2-3 months, rarely within one year [28-30]. IgM persists for much longer in the capture assays, following primary infection; in addition, these assays are more sensitive and also detect $\operatorname{IgM}$ when there is reinfection [12].

Of concern, even in such a small sample, is the finding of positive or inconclusive serologic results for toxoplasmosis, obtained in five patients, with serum tests required for both agents.

During the four years, only 21 to 30 inconclusive or positive IgM samples were detected (out of 2,851), which could have benefited from IgG avidity assays. However, the Hospital Materno-Infantil Presidente Vargas is a public institution, in which investment 
priorities have to be determined on a costeffectiveness basis. Vaccination prevents the occurrence of congenital infection, even in campaigns with a risk of inadvertently vaccinating a pregnant woman, there being no scientific evidence of congenital rubella caused by the vaccine.

For the above-mentioned reasons, it has been decided not to implement IgG avidity assays for the rubella virus in this hospital. The decision of implementing a new technique must also consider if the diagnostic resources available are properly used by the clinical staff of the institution. Without optimal integration, as is the case in the HMIPV, a school hospital, the introduction of a new test might generate false expectations and more insecurity among physicians and patients already bewildered with the amazing technological progress in the field of diagnosis.

\section{References}

1. Gregg N.M. Congenital cataract following German measles in the mother. Trans Ophthamol Soc Aust 1941;3:35-46.

2. Wesselhoeft C. Rubella (German Measles). N Engl J Med 1947;236:943-50.

3. Cochi S.L., Edmonds L.E., Dyer K., et al. Congenital rubella syndrome in the United States, 1970-1985. On the verge of elimination. Am J Epidermiol 1989;129:349-61.

4. Forrest J.M., Menser M.A., Burgess J.A. High frequency of diabetes mellitus in young adults with congenital rubella. Lancet 1971;ii:332-4.

5. Gilbert G.L., Rubella. In: Gilbert GL., editor. Infectious disease in pregnancy and the newborn infant. $2^{\text {nd }} \mathrm{ed}$. Switzerland: Hardwood Academic Press; 1997. p. 23-62.

6. Lee J.-Y., Bowden D.S. Rubella Virus Replication and Links to Teratogenicity. Clin Microbiol Review 2000;13(4):571-87.

7. Bossy-Wetzel E., Green D.R. Apoptosis: checkpoint at the mitochondrial frontier. Mutat Res 1999;434:243-51.

8. Megyeri K., Berenesi K., Halazonetis T.D., et al. Involvement of a p53-dependent pathway in rubella virus-induced apoptosis. Virology 1998;259:74-84.

9. Pugachev K.V., Frei T.K. Rubella virus induces apoptosis in culture cells. Virology 1998;250:359-70.

10. Höfmann I., Pletz M.W., Liebert U.G. Rubella virus-induced cytopathic effect in vitro is caused by apoptosis. J Gen Virol 1999;80:1657-64.
11. Takei K., Yamamoto Y.I. Rubéola. In: Ferreira A.W., Àvila S.L.M. Diagnóstico Laboratorial das Principais Doenças Infecciosas e Auto-Imunes. $2^{\text {nd }}$ ed. Rio de Janeiro, RJ: Editora Ganabara Koogan AS; 2001;116-30.

12. Cusy M.G., Valensin P.E., Cellesi C. Possibility of reinfection after immunisation with RA 27/3 live attenuated rubella virus. Arch Virol 1993;129:337-40.

13. Forsgren M., Sören L. Subclinical rubella reinfection in vaccinated women with rubella-specific IgM response during pregnancy and transmission of viruses to the fetus. Scand J Infect Dis 1985; 17:337-41.

14. Morgan-Capner P., Hambling A.H., Coleman I.J., et al. Detection of rubella-specific IgM in subclinical rubella reinfection in pregnancy. Lancet 1985; i:244-6.

15. Horstmann D.M., Schluederberg A., Emmons J.E., et al. Persistence of vaccine-induced immune responses to rubella: comparison with natural infection. Rev Infect Dis 1985;7(Suppl):80-5.

16. Hedman K., Hietala J., Tiilikainen A., et al. Maturation of immunoglobulin $\mathrm{G}$ avidity after rubella vaccination studied by an enzyme-linked immunosorbent assay (avidity-ELISA) and haemolysis typing. J Med Virol 1989;27:293-8.

17. Thomas H.I.J., Morgan-Capner P. Rubella-specific IgG subclasses avidity ELISA and its role in the differentiation between primary rubella and rubella reinfection. Epidem Inf 1988;101:591-8.

18. Abe T., Nakada H., Hatanka M., et al. Myoclonus in a case of suspected progressive rubella panencephalitis. Arch Neurol 1983;40:98-100.

19. Rawls W.E. Congenital rubella: the significance of virus persistence. Prog Med Virol 1968;10:238-85.

20. Töndury G., Smith D.W. Fetal rubella pathology. J Pediatr 1966;68:867-76.

21. Hedman K., Rousseaux S.A. Measurement of avidity of specific IgG for verification of recent primary rubella. $\mathrm{J}$ Med Virol 1989;27:288-92.

22. Thomas H.I.J., Morgan-CapnerP., Enders G., et al. Persistence of specific IgM and low avidity specific IgG1 following primary rubella. J Virol Methods 1992;39:149-55.

23. Mahoney J.B., Chernesky M.A. Rubella Virus. In Rose NR, Maccario EC, Folds JD, Lane HC, Nakamura RM. Manual of Clinical Laboratory Immunology $5^{\text {nd }}$ ed. Washington DC: American Society for Microbiology ASM Press 1997;693-8.

24. Best J., Palmer S., Morgan-CapnerP., Hodgson J.Acomparison of Rubazyme-M and MACRIA for the detection of rubellaspecific IgM. J Virol Methods 1984;8:99-109.

25. Chernesky M.A., Wyman L., Mahony J.B., et al. Clinical evaluation of the sensitivity and specificity of a commercially available enzyme immunoassay for detection of rubella virus-specific immunoglobulin $\mathrm{M}$. M J Clin Microbiol 1984;20:400-4. 
26. Abbott G.G., Safford J.W., MacDonald R.G., et al. Development of automated immunoassay for immune status screening and serodiagnosis of rubella virus infection. J Virol Methods 1990;27:227-40.

27. Parkman P.D., Meyer H.M., Kirschstein R.L., Hoops H.E. Attenuated rubella virus. Development and laboratory characterization. N Engl J Med 1966;275:569-74.

28. Cooper L.Z., Buimovici-Klein E.. Rubella. In: Fields B.N., Knipe D.M., Chanock J.L., et al. Virology. New York, NY: Raven Press, 1985:1005-20.

29. Parkmann P.D. Making vaccination policy: the experience with rubella. Clin Inf Dis 1999;28:140-6.

30. Wolinsky J.S. Rubella. In: Fields B.N., Knipe D.M., Howley P.M, Chanock RM, Melnick JL, and Roizman B. Virology $3^{\text {nd }}$. Philadelphia, Pa:Lipincott-Raven; 1996:899-929.

31. Grangeot-Keros L., Pillot J., Daffos F., Forestier F. Prenatal and postnatal production of IgM and IgA antibodies to rubella virus studied by antibody capture immunoassay. J Infect Dis 1988; 158:138-43.

32. Herrmann K. Available rubella serologic tests. Rev Infect Dis 1985; 7(Suppl): 108-12.

33. CDC. Control and prevention of rubella: evaluation and management of suspected outbreaks, rubella in pregnant women and surveillance for congenital rubella syndrome. MMWR 2001;50(RR-12):1-23. 